\title{
The helminth infracommunities of the wood mouse (Apodemus sylvaticus) two years after the fire in Mediterranean forests
}

\author{
I. TORRE ${ }^{1}$, A. ARRIZABALAGA ${ }^{1}$, C. FELIU ${ }^{2}$, A. RIBAS $^{3}$ \\ ${ }^{1}$ Museu de Granollers-Ciències Naturals C/Francesc Macià, 5108402 Granollers, Spain; ${ }^{2}$ Laboratory of Parasitology, \\ Faculty of Pharmacy, University of Barcelona, Avda Diagonal s/n 08028 Barcelona, Spain; ${ }^{3}$ Evolutionary Ecology \\ Group, University of Antwerp, Groenenborgerlaan 171, B-2020 Antwerpen, Belgium, E-mail: aribas@ub.edu
}

\begin{abstract}
Summary
Parasites have been recognized as indicators for natural or man-induced environmental stress and perturbation. In this article, we investigated the role of two non-exclusive hypotheses on the response of helminths of wood mice to fire perturbation: 1) a reduction of the helminth infracommunity (species richness) in post-fire areas due to the temporal lack of worms with indirect (complex) life cycles linked to intermediate hosts that are more specialized than the final host, and 2) an increase of the abundance of helminths with direct (simple) life cycles as a response of increasing abundances of the final host, may be in stressful conditions linked to the post-fire recolonization process.

We studied the helminth infracommunities of 97 wood mice in two recently burned plots (two years after the fire) and two control plots in Mediterranean forests of NE Spain. Species richness of helminths found in control plots $(n=14)$ was twice large than in burned ones $(n=7)$. Six helminth species were negatively affected by fire perturbation and were mainly or only found in unburned plots. Fire increased the homogeneity of helminth infracommunities, and burned plots were characterised by higher dominance, and higher parasitation intensity. We found a gradient of frequency of occurrence of helminth species according to life cycle complexity in burned areas, being more frequent monoxenous (66.6\%), than diheteroxenous (33.3\%) and triheteroxenous $(0 \%)$, confirming the utility of helminths as bioindicators for ecosystem perturbations. Despite the short period studied, our results pointed out an increase in the abundance and prevalence of some direct life cycle helminths in early postfire stages, whereas indirect life cycle helminths were almost absent. A mismatch between the final host (that showed a fast recovery shortly after the fire), and the intermediate hosts (that showed slow recoveries shortly after the fire), was responsible for the loss of half of the helminth species.
\end{abstract}

Keywords: Apodemus; fire; infracommunities; recolonization

\section{Introduction}

For centuries, Mediterranean ecosystems have been regularly affected by natural or man-induced perturbations (ie, floods, fires, droughts, etc., Blondel \& Aronson, 1999). Among these perturbations, fires are considered as essential components of the dynamics of Mediterranean-type ecosystems (Moreno \& Oechel, 1994), altering species composition and abundance of several species of animals and plants (Trabaud \& Prodon, 1993; Terrades, 1996, and references therein). Parasites have been recognized as indicators (or biological tags) for natural or man-induced environmental stress and perturbation (Galán-Puchades \& Fuentes, 1996; Marcogliese \& Cone, 1997), tracking the effects of human impacts on the environment (Lafferty, 1997). This interesting property of parasites relies on the strict dependence of their hosts (Fuentes et al., 2007), and the response of the intermediate and final hosts to fire will determine the presence of parasites.

In the Mediterranean Region, helminths of small mammals have been used as models of the post-fire recolonization process (Feliu et al., 1993; Fuentes et al. 1998, 2005, 2007; Fons et al., 1988; Galán-Puchades et al., 1999; Prodon et al., 1987; Sainz-Elipe et al., 2007; Torres et al., 1992). Despite most studies did not find differences in the helminth species composition of control and post-fire stages shortly after fire, some authors suggested a decrease in helminth species richness in post-fire areas compared to unburned areas (Feliu et al., 1993; Fuentes et al., 1998, 2007; Torres et al., 1992). This loss of helminth diversity in post-fire areas can be understood because of the difficulty of some species to complete their indirect life cycles in perturbed areas. Nonetheless, higher prevalences and intensities of some helminth species with direct life cycles can be considered as representative of post-fire stages (Feliu et al., 1993; Fuentes et al., 2007; Torres et al., 1992).

The wood mouse (Apodemus sylvaticus) is a generalist gra- 
nivorous/insectivorous rodent widely distributed across different habitats and elevations of Spain (Jubete, 2007) and Europe (Montgomery, 1999), and one of the most studied small mammals hosts of helminth parasites (Feliu et al., 1987, recently studied by Eira et al., 2006; Goüy de Bellocq et al., 2003; Milazzo et al., 2005; 2010; Nierbering et al.; 2006; Ondriková et al., 2010). Prevalence and abundance of parasitic helminths in wood mice are known to depend on several extrinsic (climate, season, habitat, food availability) and intrinsic (age, sex, body condition, density) factors (Abu-Madi et al., 2000; Díaz \& Alonso, 2003; Eira et al., 2006). Among extrinsic factors, habitat quality is the one that can be more affected after a fire, producing strong changes in the vegetation composition and structure, and in the animal communities (Prodon et al., 1987), and some of them can be long lasting (ie, those affecting to litter arthropods, Prodon et al., 1987). Nonetheless, shortly after a fire, small mammals can take advantage of the high availability of food and refuges that can be found in the post-fire habitats according to the resprouting of herbaceous and shrubby vegetation, and the lack of predators (Torre \& Díaz, 2004). Under this favourable situation, wood mice are more abundant in burned than in control areas (Prodon et al., 1987; Fuentes et al., 1998; Torre \& Díaz, 2004), and the recolonization process undertaken by this species (ie dispersal strategy) may affect the recolonization process by parasites. In this sense, under higher densities of wood mice hosts, some direct life cycle parasites can be favoured (Fuentes et al., 2005).

According to some consistent patterns detected in helminthological studies and ecological studies of wood mice, fire perturbations may affect parasites in two opposite ways, 1) by reducing parasitic loads of indirect life cycle helminths because of the destructuration of communities due to the lack of intermediate and final hosts (Feliu et al., 1987; Prodon et al., 1987), and 2) by enhancing parasitic loads of direct life cycle parasites due to increased abundance of their final hosts (Díaz \& Alonso, 2003; Fuentes et al., 2007).

\section{Material and methods}

The study was carried out in the Montseny Natural Park and Reserve of the Biosphere (Barcelona, Catalonia, NE Spain; 41 ${ }^{\circ} 46^{\prime}$ N, $2^{\circ} 23^{\prime}$ E, 29960 ha). In summer of 1994 a wildfire affected the Natural Park, as well as many other natural areas of Catalonia. The fire started the 10 august 1994 and was active for 48 hours, burning 9.000 ha, 752 ha within the limits of the Natural Park (Boada, 1995).

We established four plots, two control and two burned. Both control plots were separated $500 \mathrm{~m}$, and both burned plots were separated $1000 \mathrm{~m}$. Distance between the control and burned area was $4.500 \mathrm{~m}$. Cork oak forest Control. The plot was placed at 550 m.a.s.1.. The canopy cover was dominated by Quercus suber trees, followed by Quercus ilex and Pinus pinea. Holm oak forest Control. The plot was set at 600 m.a.s.l. Canopy cover was of about $65 \%$, with Quercus ilex being dominant, followed by Quercus suber, Quercus humilis and Castanea sativa. Cork oak forest Burned. This plot was set at 550 m.a.s.l. The plot was completely affected by the fire, but Quercus suber trees resprouted from branches during the spring-summer of 1995 , one year after the fire. Tree cover was about $25 \%$. Pinus pinea that were burned and died by fire were cut. Holm oak forest Burned. The plot was set at 550 m.a.s.1.. and was completely affected by the fire, and Quercus ilex dead tree trunks were removed from the plot. One year after the fire Quercus ilex resprouted from the roots and cut stems. Quercus suber trees resprouted from branches and were not removed.

Sampling was performed during 1996 on the four plots during three seasonal trapping sessions (spring, summer and fall) of three days each. Every plot was sampled by a 7 x 7 trapping grid, with 49 Sherman traps (Sherman folding small animal trap; 23 x $7.5 \times 9 \mathrm{~cm}$; Sherman Co., USA) spaced $15 \mathrm{~m}$ apart (covering about $1 \mathrm{ha}$ ), and open for three consecutive nights.

Traps were baited with a piece of apple and a mixture of tuna, flour and oil, and were set under the cover of shrubs or dense herbs to conceal them and to provide some thermal insulation. The small mammals caught were identified to species, marked by toe-clipping (Adler et al., 1999; Gurnell \& Flowerdew, 1990), and released at the point of capture. We used counts (eg the number of different individuals trapped within the three days, Morris, 1996) as a biased estimate of population size in each study plot, assuming that the unseen proportion of the population is constant (Slade \& Blair, 2000), and that in some situations, counts and estimates yielded similar results (Slade \& Blair, 2000). According to recommendations, we did not apply unbiased estimators of population size due to the low number of sampling occassions (Slade \& Blair, 2000).

Only individuals that were found dead within traps were used for parasitological studies (see Torres et al. 1992; Feliu et al. 1993; Fuentes et al. 1998, 2007; for the same approach). Viscera were separated and frozed until dissection was performed. Dissections were performed under an esteroscopic microscope; isolated helminths were mounted in slides following standard helminthological methods.

Accuracy of prevalence estimates are subject to the number of individuals hosts sampled, and hence, to sample size (Jovani \& Tella, 2006). In this study, sample sizes for the levels of the factors analysed were near to or higher than the minimum recommended ( $>15$ individuals, Jovani \& Tella, 2006). The total number of hosts analyzed and parasite individuals identified varied among sampling grids, and we used rarefaction to provide a meaningful interpretation of species richness between parasite infracommunities. We used Estimate S 7.50 software (R.K. Colwell, available at http: //viceroy.eeb.uconn.edu/ estimates) to generate sample-based (host-based) and individual-based rarefaction curves of helminth species richness. Finally, Shannon diversity, PIE Hulbert's (a measure of evenness), and Dominance indices were calculated for every sampling plot using rarefaction curves by means of Ecosim 7.0 software (Gotelli \& Entsminger, 2001) to detect patterns between burned and unburned habitats. 
Statistical log-linear models for multidimensional contingency tables (Zar, 1996) were used to test for differences in the prevalence (proportion of the number of individuals infected to the number of individuals not infected) and frequency of occurrence of the helminth species, by treatment (control and burned) and habitat (cork oak and hom oak). The analysis of prevalence with contingency tables is extensively used by parasitologists (Abu-Madi et al., 2000), despite other approaches are also recommended (Jovani \& Tella 2006). Only helminth species considered as component (prevalence $\geq 10 \%$, Bush et al., 1997) were analysed and interpreted. The standardized residuals after the log-linear analyses were used to represent the degree of deviance from the null model (no associations between factors), and the statistical significance within levels of a factor was verified examining the components of maximum likelihood, comparing these values with the critical level of significance for 1 degree of freedom $\left(\mathrm{Chi}^{2}=3.84\right.$, $P<0.05)$ (Flaquer et al., 2007).

Mean species richness and mean number of helminths per host depending on the treatment (burned and control) and the sex of the host were analysed with GLM (factorial twoway ANOVA), whereas tests on species abundance were performed with the Kruskal-Wallis test because of high parasite aggregation (Díaz \& Alonso, 2003). Spatial aggregation of helminth individuals among wood mice hosts was analysed with the mean/variance ratio (Ludwig \& Reynolds, 1988; Fuentes et al., 2007, for a similar approach).

Number of helminths and species richness per host were conveniently transformed $(\log (\mathrm{X}+1)$ for abundance and square root transformation for richness) to reach homoscedasticity and normality criteria for GLM analyses (Zar, 1996).

\section{Results}

During the study period 529 wood mice were trapped in the four study plots. As a whole, high number of individuals were captured in burned than in control areas (burned: 157 and 154 individuals, and control: 80 and 138 individuals, holm oak and cork oak grids, respectively; $\mathrm{Chi}^{2}=$ 16.34, df $=1, \mathrm{p}<0.0001) .97$ wood mice were found dead in traps and were considered for the helminthological study. 64 individuals were from the control grids, and 33 were from burned grids.

\section{Helminthological infracommunities and fire}

The helminth species found and their prevalences and abundances within wood mice hosts in the control and burned plots are shown in table 1. Number of species of helminths found in control plots was twice as high as in burned ones (14 versus 7 species). Nonetheless, since the number of hosts analysed was higher in control than in burned grids (64 and 33 wood mice, respectively), we used rarefaction curves to control for differences in sampling effort between treatments. Either sampled-based (or hostbased) curves and individual-based curves showed higher helminth species richness in the control grids (Fig. 1).
The species richness patterns were further confirmed after a factorial two-way ANOVA performed with the number of helminth species per host as the response variable, considering treatment and sex as fixed factors, and their interaction. Mean species richness per host was higher in control $(2.90 \pm 0.16 S E)$ than in burned $(2.15 \pm 0.22 S E)$ plots $\left(\mathrm{F}_{1,93}=5.51, \mathrm{p}=0.02\right)$, but was unaffected by sex of the host $\left(\mathrm{F}_{1,93}=0.54, \mathrm{p}=0.46\right)$, without interactive effects $\left(\mathrm{F}_{1}\right.$, $\left.{ }_{93}=1.26, \mathrm{p}=0.26\right)$. Mean helminth abundance per host was higher in burned $(58.93 \pm 7.17 \mathrm{SE})$ than in control $(41.73 \pm 5.15 S E)$ plots $\left(\mathrm{F}_{1,93}=4.66, \mathrm{p}=0.03\right)$, but was unaffected by the sex of the host $\left(\mathrm{F}_{1,93}=0.19, \mathrm{p}=0.65\right)$, without interactive effects $\left(\mathrm{F}_{1,93}=0.38, \mathrm{p}=0.53\right)$. Due to the relatively low number of hosts analysed and owing to the lack of sexual differences in infection rates as well as abundance of parasites, we did not consider sex as a factor in further analyses.

Shannon diversity and PIE Hulbert's indexes of the helminth infracommunity were higher in control than in burned plots, whereas dominance was higher in burned than in control plots (Fig.2).

A log-linear analysis of the frequency distribution of the helminth species richness showed similarity in control and burned grids (interaction Treatment x Number of Helminth Species: $\left.\mathrm{G}_{7}^{2}=7.36, \mathrm{p}=0.39\right)$. Prevalences were extremely high in both control $(98.5 \%)$ and burned (100\%) grids, since all but one of the individuals analysed were parasited by at least one helminth species. In both control and burned grids the highest proportion of hosts were parasited by two helminth species (34.4\% and $51.5 \%$, respectively), followed by three species $(29.6 \%$ and $30.3 \%$, respectively), and one species (10.9 \% and $18.2 \%$, respectively). Nonetheless, qualitative differences were observed since in burned grids infection was produced by 1 - 3 species per host, whereas in control grids infection was produced by $1-7$ different helminth species per individual host.

\section{Specific responses of helminths to habitat and fire pertur- bation}

As a general pattern, wood mice infracommunities two years after the fire were dominated by Heligmosomoides polygyrus (showing higher abundance and aggregation), whereas infracommunities in unburned areas were dominated by Syphacia stroma (showing higher abundance and aggregation). In order to understand better the responses of helminth species in control and burned plots, we analysed two-way contingency tables (Species $\mathrm{x}$ Treatment) by means of log-linear models for both habitats separately. In the holm oak grid, 8 out of 14 species $(57.14 \%)$ showed significant responses to fire (Species $\mathrm{x}$ Treatment: $\mathrm{G}_{13}^{2}=$ $484.35, \mathrm{p}<0.0001$ ), but only two species responded positively to fire (increased abundance in burned plot), and the other six were negatively affected by fire (Fig. 3A). In the cork oak grid, 7 out of 14 species $(50.0 \%)$ showed significant responses to fire (Species x Treatment: $\mathrm{G}^{2}{ }_{13}=752.76$, $\mathrm{p}<0.0001$ ), but only one species responded positively to fire (increased abundance in burned plot), and the other six 

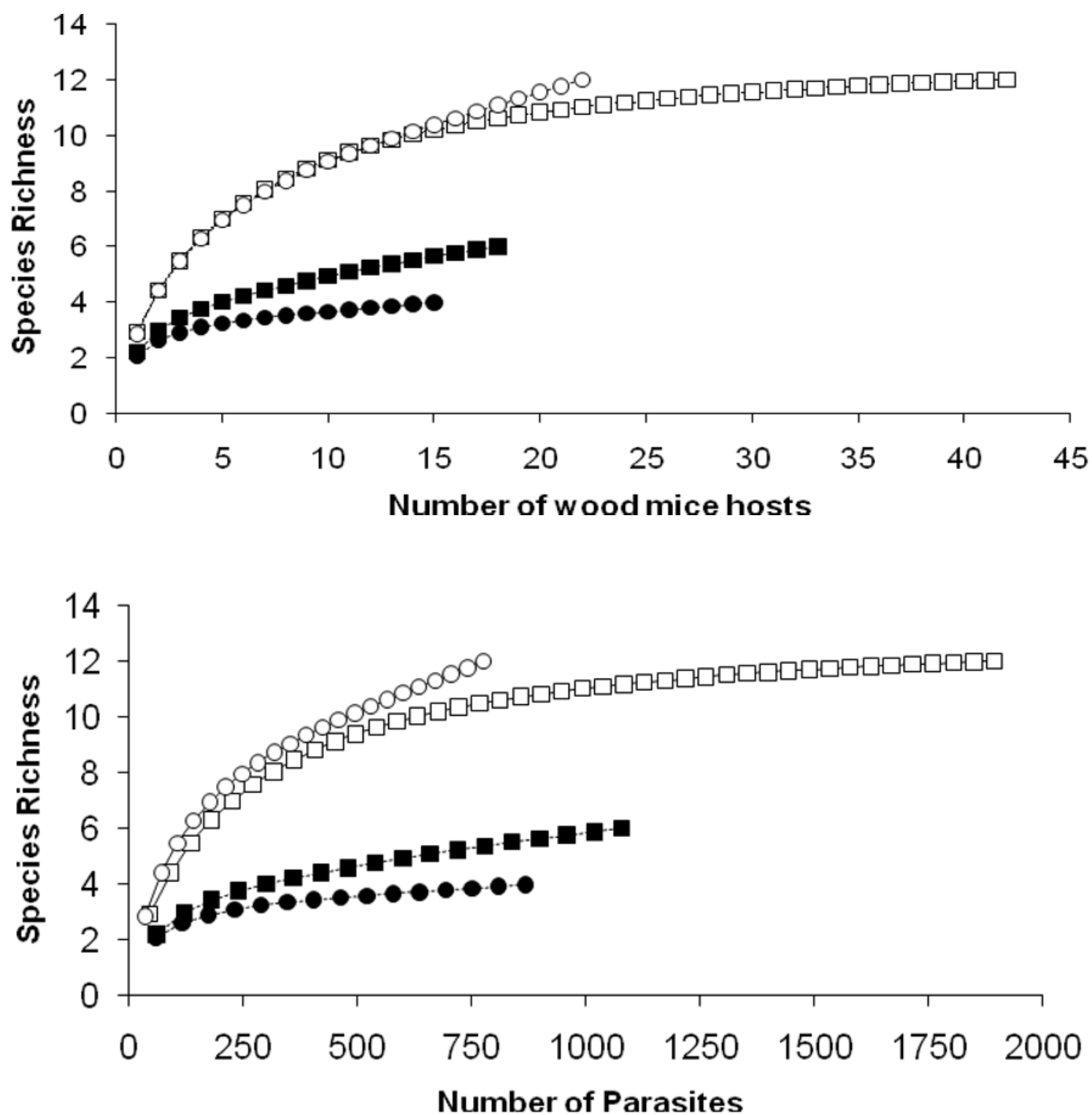

Fig. 1. Rarefaction curves for the species richness of the helminthological infracommunity of wood mice rescaled according to A) the number of hosts analysed, and B) the number of parasites identified, in the four plots studied.

Legend: open simbols: control; solid simbols: burned; circles: holm oak plots, squares: cork oak plots

were negatively affected by fire (Fig. 3B). The graphical representation of the standardized residuals after the loglinear analyses of the contingency tables showed the helminth species whose abundance was positively or negatively affected by fire in both habitats studied (Fig. 3). The analyses of mean helminth abundance per host depending on the treatment (burned and control) showed identical results than prevalences for almost all the species (Table 1).

The helminth species were gathered in three groups depending on the response of prevalence and abundance to the perturbation (fire): species whose prevalence and abundance 1) increased with perturbation, 2) were unaffected by perturbation, and 3 ) decreased with perturbation (Table 1).

The first group was composed by $H$. polygyrus, which was the helminth species with the highest prevalence
(91.75\%), and S. frederici. Both species had higher prevalences and abundances per individual host in burned areas. $H$. polygyrus was four times more abundant in wood mice from burned than from control grids. This species increased its pattern of aggregation per individual host (clumping) from control to burned areas (variance/mean ratio: 8.55 vs 27.37). The second group was composed by 1 helminth species, $S$. stroma, and was the only helminth species that showed similar prevalences in both burned and control areas. S.stroma showed strong clumped patterns that decreased from control to burned areas (variance/mean ratio: 65.45 vs 17.6).

The third group was composed by 6 species whose prevalences and abundances decreased in the burned areas. Some species, like M. muris, G. arfaai, and E. bacillatus, showed lower prevalences in burned areas, and some other 

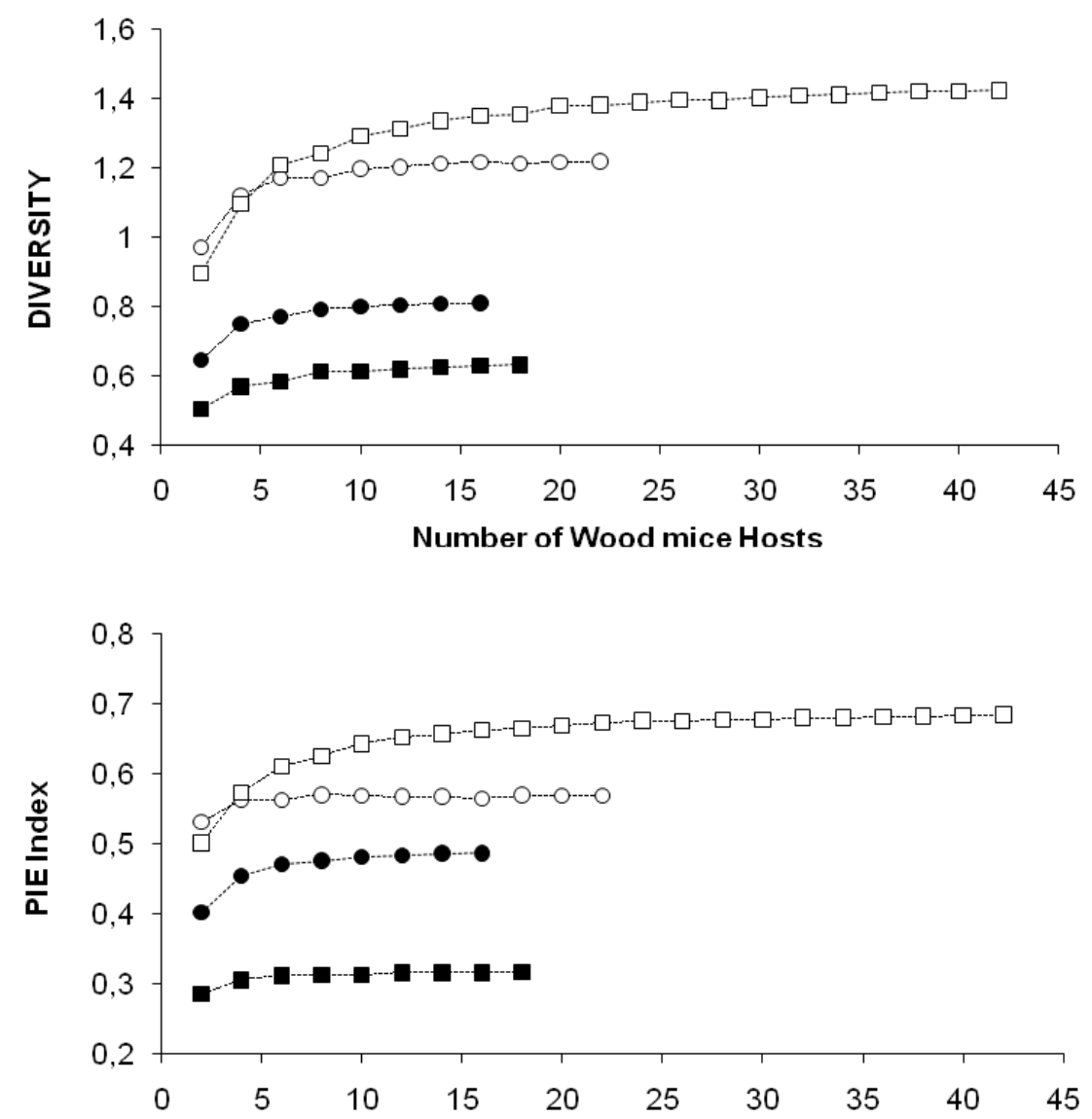

Number of Wood mice Hosts



Fig. 2. Sample-based (host-based) rarefaction curves for Shannon diversity index, PIE Hulbert's index, and dominance of the helminth communities of wood mice in the four sampling plots. Legend as in Fig.1

species were absent from burned areas (A.murissylvatici, T.muris, and C. vitta), despite all of them showed higher prevalences in control areas $(>10 \%)$.

Other species showed lower prevalences in control areas $(<$ $5 \%$ ) and were absent from burned areas (S. lobata, Brachylaima sp., R. straminea, and T. martis), but we have some uncertainity since samples from burned areas consisted on low number of hosts analysed, so differences in prevalences might well reflect some sampling biases. The same can be applied to T. parva that was found in both control and burned areas.

Finally, we groupped helminth species according to their biological cycle in three categories: monoxenous, diheteroxenous, and triheteroxenous, to analyse the effect of perturbation on helminth species. Four out of six monoxenous helminth species found in the control areas were also found in the burned areas $(66.6 \%)$, two out of six diheteroxenous helminths found in the control areas were also 


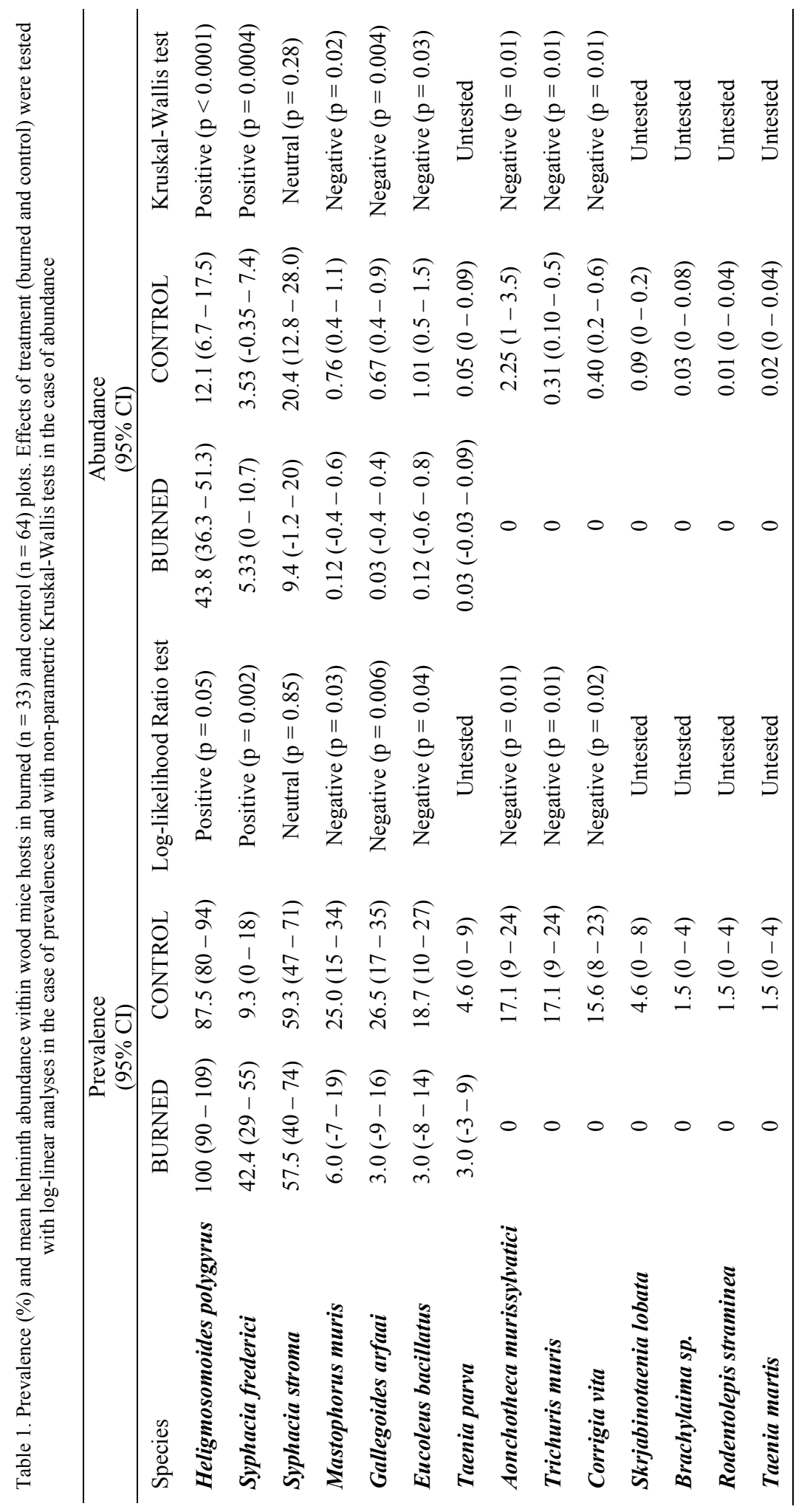



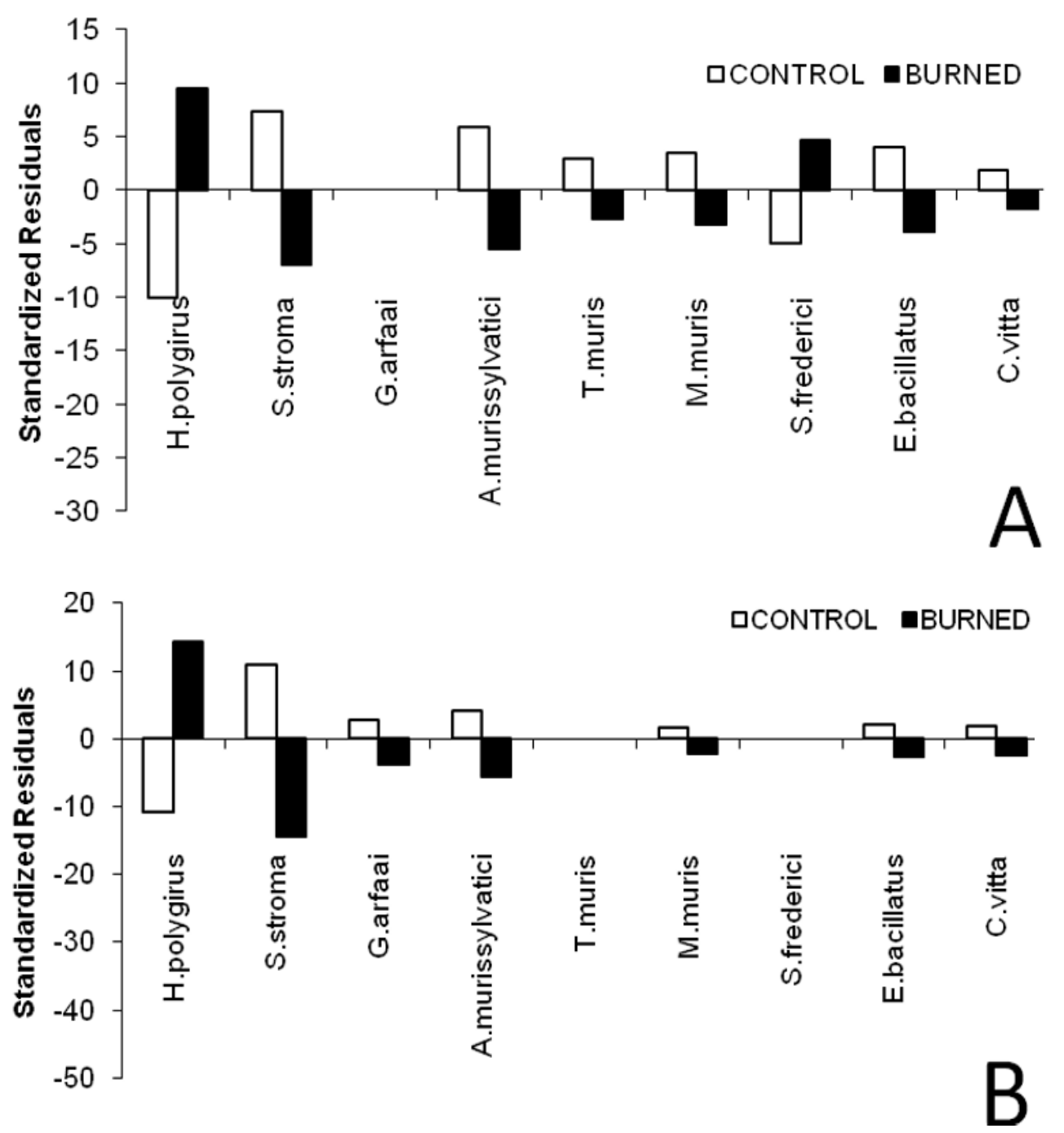

Fig. 3. Standardized residuals after the two log-linear analyses performed with the helminth species abundance in wood mice hosts from the holm oak (A) and the cork oak (B) plots, depending on the treatment of plots (burned and control). All plotted residuals are significantly different from zero.

found in the burned areas $(33.3 \%)$, and none of the two triheteroxenous helminths found in the control areas were found in the burned areas $(0 \%)$.

A two-way factorial ANOVA of mean prevalence showed that this variable was affected by complexity of the life cycle $\left(\mathrm{F}_{2,22}=4.91, \mathrm{p}=0.01\right)$, and was marginally affected by treatment $\left(\mathrm{F}_{1,22}=3.17, \mathrm{p}=0.08\right)$, without interactive effects $\left(\mathrm{F}_{2,22}=0.16, \mathrm{p}=0.84\right)$. A two-way factorial ANOVA of mean abundances showed that this variable was affected by complexity of the life cycle $\left(\mathrm{F}_{2,22}=7.24, \mathrm{p}\right.$ $=0.003)$, but was unaffected by treatment $\left(\mathrm{F}_{1,22}=0.22, \mathrm{p}=\right.$ $0.64)$, without interactive effects $\left(\mathrm{F}_{2,22}=0.00, \mathrm{p}=0.99\right)$. The lack of significance in prevalence and abundance by treatment can be related to high variance in both variables depending on the life cycle complexity. Once analysing separately the effect of fire on the prevalence and abundance of helminths of simple (monoxenous) and complex life cycles (heteroxenous), we observed that both variables were unaffected by fire in the former (Prevalence: $F_{1,14}=$ $0.33, \mathrm{p}=0.57$; Abundance: $\mathrm{F}_{1,14}=0.06, \mathrm{p}=0.80$ ), but were affected by fire in the latter (Prevalence: $\mathrm{F}_{1,14}=9.67$, $\mathrm{p}=0.007$; Abundance: $\left.\mathrm{F}_{1,14}=4.57, \mathrm{p}=0.05\right)$ (Fig.4).

\section{Discussion}

In this study we have compared the infracommunities of helminths parasiting wood mice from two recently burned areas (two years after the fire), and two undisturbed areas in the Montseny Natural Park (NE Spain). Despite the short term period studied, our results supported the role of two alternative, but non-mutually exclusive, hypotheses in explaining the recovery of helminth infracommunities after the fire: 1) a reduction of the helminth infracommunity (species richness) in recently burned areas due to the temporal lack of species with complex life cycles linked to intermediate hosts (Prodon et al., 1987; Torres et al., 1992), and 2) an increase of the abundance of parasites as a response of increasing abundances of the final hosts, may be in stressful conditions linked to the post-fire recolonization process (aggregation of hosts, Fuentes et al., 2007). 

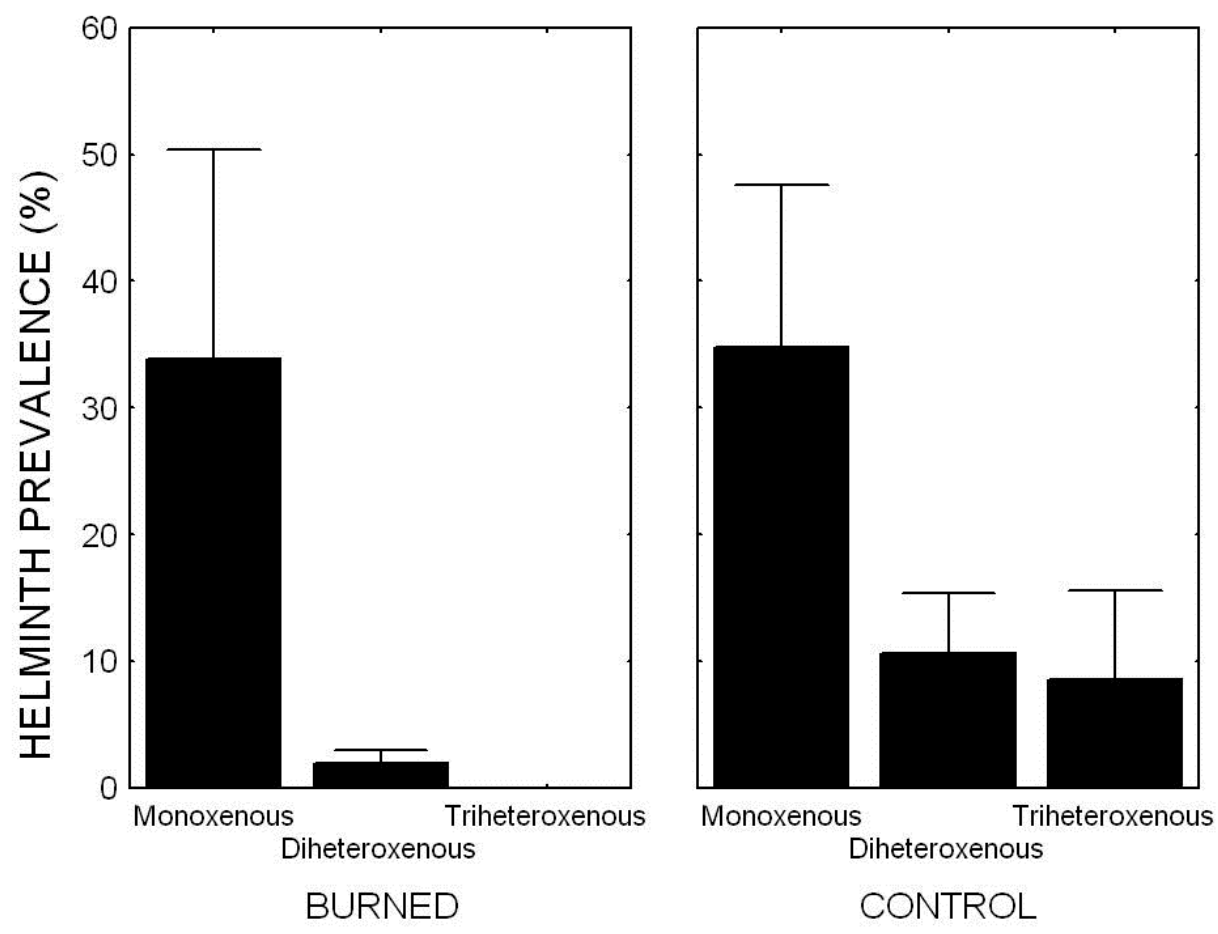

Diheteroxenous

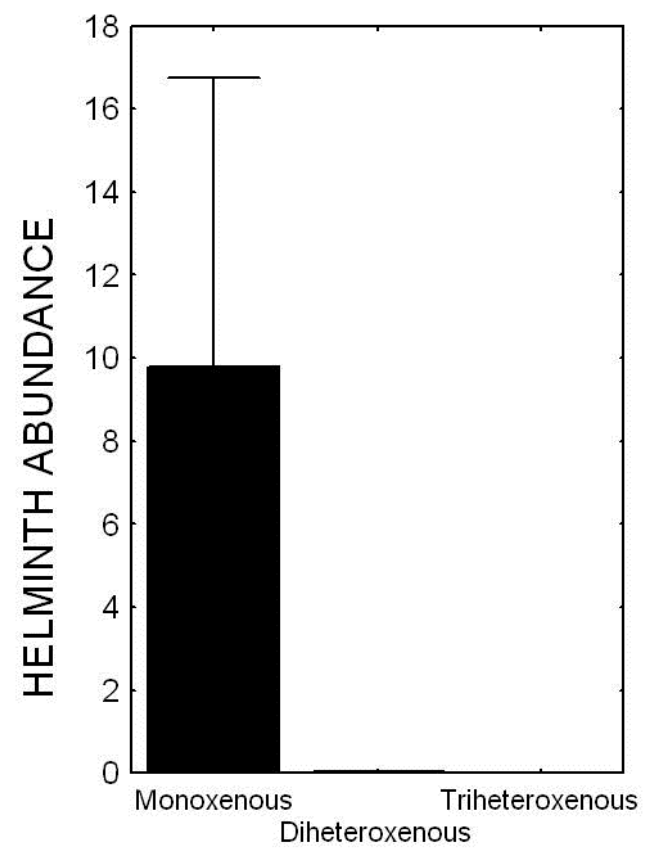

BURNED
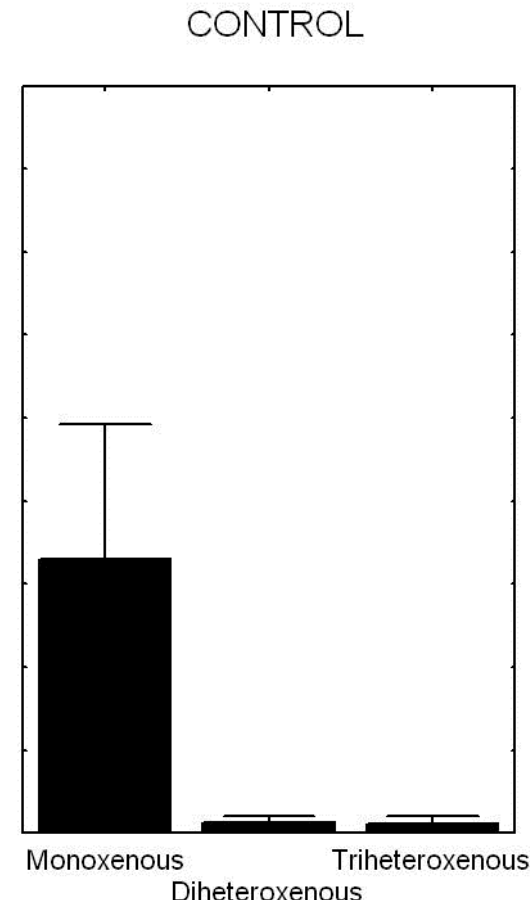

Diheteroxenous

CONTROL

Fig. 4. Mean values ( \pm SE) of prevalence and abundance of helminth species in wood mice hosts according to the biological cycle (monoxenous, diheteroxenous and triheteroxenous) in burned and control grids

Studies on post-fire recolonization by small mammals are relatively numerous in the Mediterranean Region (Arrizabalaga et al., 1993; Fons et al., 1988; Fuentes et al., 1998; Haim \& Izhaki, 1994; Prodon et al., 1987; Torre \& Díaz, 2004), but studies on post-fire recolonization of the small mammal helminths are relatively scarce (Feliu et al., 1993; Fuentes et al., 1998, 2005, 2007; Sainz-Elipe et al., 2007; Torres et al., 1992). Parasites can be considered as biological tags for post-fire recolonization studies owing the close relationships with their hosts (Fuentes et al., 2007). The presence of a helminth species in a disturbed community ultimately depends on the presence of its intermediate hosts (mostly invertebrates) and its final hosts (mostly mammals), which in turns depends on the ability and strategy of the different hosts to recolonize disturbed habitats (Galán-Puchades et al., 1999). The wood mouse is 
a common final host of helminths in post-fire habitats (Fuentes et al., 1998, 2007), having a high capacity of post-fire recolonization (Monimeau et al., 2002), and being found in early post-fire stages $(1-5$ years after the fire: Arrizabalaga et al., 1993; Fuentes et al., 1998; Fons et al., 1988; Prodon et al., 1987; Torre \& Díaz, 2004). Our results are in agreement with the fast recovery of wood mice populations after the fire. Wood mice are generalist rodents that recolonize post-fire areas according to habitat features (ie, food availability, antipredatory refuges, Torre \& Díaz, 2004), and this process nearly matches changes in vegetal composition and structure that occurred during post-fire succession (Torre \& Díaz, 2004).

Invertebrates (intermediate hosts) are strongly affected by fire, and these kind of perturbations may be long lasting for this group (ie, complete recovery may last more than 20 years, Prodon et al., 1987). Despite we did not have information on invertebrates communities in the sampling plots, we are able to suspect that those communities were significantly affected by perturbation two years after the fire. Since post-fire recolonization by parasites depends on the recovery of animal hosts (either intermediate and final hosts), we may hypothesise that the lack of half of the helminth species in the infracommunities of wood mice from burned plots was a consequence of the lack of intermediate hosts (the final host, wood mouse, was present). In this sense, the incapacity of post-fire recolonization of intermediate hosts species may be responsible of the absence of several helminth species, especially those with complex life cycles (ie, heteroxenous). As has been stated by Prodon et al. (1987), the impact of fire on parasite communities may be a consequence of the destruction of eggs and larval stages of intermediate hosts and the unfavourability of the edafic conditions for parasite establishment. A missmatch between the final host (that showed a fast recovery after the fire), and the intermediate hosts (that showed slow recoveries after the fire), might be responsible for the loss of half of the helminth richness infracommunity in the recently burned areas studied.

Our results on helminth species richness patterns two years after the fire were different to those reported by the published studies about wood mice helminth communities and fire (Feliu et al., 1993; Fuentes et al., 1998, 2007; Torres et al., 1992). These authors found that helminth communities had higher or similar species richness in recent post-fire stages (two years after the fire) than in unburned areas. These, somehow, surprisingly results were interpreted by those authors according to the particular responses of wood mice to fire, which survived within the burned area and hence, conserved their complete helminth infracommunity of the unburned area (Fuentes et al., 1998), or were captured in the burned area as a consequence of temporal and occasional migrations from nearby unburned areas (Torres et al., 1992). Other factors related to fire perturbations, like extension and intensity of fire, may be responsible of a perceived fast recovery of helminth communities after the fire, as was hypothesised by Galán-Puchades et al. (1999). Our results suggested that all helminth species arrived with wood mice from nearby unburned areas to burned areas during the two years after the fire, but ecological conditions of burned areas were not suitable to allow establishement of half of the helminth species present in unburned areas. These results were confirmed due to the negative responses (ie, prevalence and abundance) of most of the helminth species to fire, especially those requiring intermediate hosts to complet their life cycle (Prodon et al., 1987), and positive responses of monoxenous helminth species like H. Polygyrus (Torres et al., 1992, Feliu et al., 1993). In fact, we found a gradient of frequency of occurrence of helminth species according to the complexity of the life cycle in burned areas, being more frequent monoxenous $(66.6 \%)$, than diheteroxenous $(33.3 \%)$ and triheteroxenous $(0 \%)$. These particular responses of helminth species in front of perturbations were previously demonstrated by Kadlec et al. (2003) in the case of floods on parasites of fishes, and by the studies by Fuentes and coworkers in post-fire habitats (Fuentes et al., 1998, 2007). Higher frequencies of occurrence of heteroxenous helminths in burned areas reported by Fuentes et al., (1998), as compared with our results, may reflect differences in intensity and extension of fire perturbations.

We found similar prevalences in burned and unburned plots, and this pattern was contrary to expectations. Higher prevalences might be expected in burned areas because of higher densities of small mammals in post-fire habitats, being responsible of the fast process of recolonization by some helminth species with direct life cycles, which take advantage of post-fire areas with high density of hosts (Fuentes et al., 1998, 2007; and references therein). The higher prevalences found in our study (100\% in burned, and $98.5 \%$ in control areas) can be interpreted according to the exceptional and favourable environmental conditions along the study period, since during 1996 the study area received twice as much rainfall than in normal years (Torre \& Arrizabalaga 2008). Rainfall can be considered as a proxy for productivity in ecosystems (Mittelbach et al., 2001), and is known to produce a significant increase in herbaceous cover, seed densities (Ernest et al., 2000; Gutiérrez et al. 1993; Meserve et al., 2001), and insect populations (Fuentes \& Campusano, 1985). During the study year in the same area we observed a significant increase of wood mice populations that was related to increasing rainfall (Díaz et al., 2010), and a fast recovery of post-fire vegetation was observed (Obon, 1997). We may hypothesise that intermediate hosts (invertebrates) were also beneffited by the wet environment, producing favourable conditions to helminth infection (high densities of intermediate and final hosts) and resulting in increasing prevalences in burned and control areas. So, global prevalence could be affected by exogenous factors independent to the perturbation (ie, climate), and the use of this variable as a biological tag (as suggested by Fuentes et al., 2007) needs further investigation. Nonetheless, mean global parasite abundance was higher in burned than in control areas, and this pattern can be seen as typical from burned areas an can be considered as a consistent biological tag 
for this kind of perturbations (Fuentes et al., 1998, 2007). However, high aggregation patterns of monoxenous helminths in burned areas was not observed in the present study, and aggregation patterns were affected by fire depending on the species. In general, the two dominant helminth species (H. polygyrus and S. stroma) showed opposite patterns of aggregation, suggesting some degree of competition.

Species richness estimates can be affected by sample size (Gotelli \& Colwell, 2001), and this has been confirmed for other helminth infracommunities (Ribas et al., 2007) and in the present study. In this sense, the analysis of species richness by means of sample-based (host-based) or individual-based rarefaction curves can be an effective solution to control for sample size differences in parasite species richness.

Despite our results can be considered as preliminary, since the study period was very short (only the second year after the fire), we hypothesised that helminth infracommunity recovery after fire occurred following the secondary succession, burned plots showing lower helminth diversity due to the lack of intermediate hosts in early post-fire stages. So, we would expect an increase of helminth infracommunity diversity with time elapsed after the fire, matching the same diversity than control areas when the cicatrization has been reached. These results are different to those reported by other authors (Feliu et al., 1992; Fuentes et al., 1998, 2007; Torres et al., 1992) who described higher or similar helminth diversity in recently burned than in control plots, suggesting a progressive loss of diversity as far as post-fire succession advanced (Fuentes et al., 1998, 2007).

\section{Acknowledgments}

The authors wish to thank the logistic and financial support of the Montseny Natural Park throughout these years (Oficina Tècnica de Parcs Naturals, Diputació de Barcelona). Dr. Mario Díaz (IRN-CCMA-CSIC) provided some useful comments in preliminary versions to improve the manuscript. AR is visiting postdoctoral fellow with FWO. This study was partuially supported by Generalitat de Catalunya 2009SGR403.

\section{References}

Abu-Madi, M. A., BehnKe, J. M., LeWIS, J. W., Gilbert, F. S. (2000): Seasonal and site specific variation in the component community structure of intestinal helminths in Apodemus sylvaticus from three contrasting habitats in south-east England. J. Helminthol., 74: 7 - 15. DOI: 10.1017/S0022149X00000020

Adler, G. H., Mangan, S. A., Suntsov, V. (1999): Richness, abundance, and habitat relations of rodents in the Lang Bian mountains of southern Viet Nam. J. Mammal., 80: 891 - 898. DOI: $10.2307 / 1383257$

Arrizabalaga, A., Montagud, E., Fons, R. (1993): Post-fire succession in small mammal communities in the
Montserrat Massif (Catalonia, Spain). In: TRABAUd L., ProdON R. (Eds) Fire in Mediterranean Ecosystems. Ecosystems Research Report 5, Commission of the European Communities. Brussels, pp. $281-291$

Blondel, J., Aronson, J. (1999): Biology and Wildlife of the Mediterranean Region. Oxford University Press, Oxford BoADA, M. (1995): Montseny, focs de l'estiu de 1994. Monografies del Montseny, 10: 45 - 60

Bush, A. O., LAfferty, K. D., Lotz, J. M., Shostak, A. W. (1997): Parasitology meets ecology on its own terms: Margolis et al revisited. J. Parasitol., 83: 575 - 583. DOI: $10.2307 / 3284227$

COLWELL, R. K. (2005): Estimate S: Statistical estimation of species richness and shared species from samples. Version 7.5. Persistent URL < purl.oclc.org/estimates>

DíAZ, M., Alonso, C. L. (2003): Wood mouse Apodemus sylvaticus winter food supply: density, condition, breeding, and parasites. Ecology, 84: 2680 - 2691. DOI: 10.1890/020534

DíAZ, M., Torre, I., Peris, A., TenA, L. (2005): Foraging behavior of Wood mice as related to presence and activity of Genets. J. Mammal., 86: 1178 - 1185. DOI: 10.1644/04MAMM-A-127R1.1

DíaZ, M., Torre, I., ArrizabalagA, A. (2010): Relative roles of density and rainfall on Mediterranean wood mouse (Apodemus sylvaticus) populations. Acta Theriol., 55: 251 - 260. DOI: 10.4098/j.at.0001-7051.046.2009

Eira, C., Torres, J., VingadA, J., MiQuel, J. (2006): Ecological aspects influencing the helminth community of the wood mouse Apodemus sylvaticus in Dunas de Mira, Portugal. Acta Parasitol., 51: 300 - 308. DOI: 10.2478/s11686-006-0046-0

Ernest, S. K. M., Brown, J. H., Parmenter, R. R. (2000): Rodents, plants, and precipitation: Spatial and temporal dynamics of consumers and resources. Oikos, 88: $470-482$

Feliu, C., Gracenea, M., Torregrosa, M. (1987): Consideraciones ecológicas sobre la helmintofauna de Apodemus sylvaticus (Linnaeus, 1758) (Rodentia: Muridae) en el Pirineo Oriental español. In: SANS-COMA, V., MASComas, S., GosálBez, J. (Eds) Mamíferos y helmintos. Ketres Editora, Barcelona, 175 - 181

Feliu, C., Fons, R., Mas-Coma, S., Galan-Puchades, M. T., Fuentes, M., Blasco, S., Grabulosa, I. (1993): The helminth parasites as markers on the dynamics of micrommamals recolonisation after fire. In: TRABAUD L, Prodon R. (Eds). Fire in Mediterranean Ecosystems. Commission of the European Communities, Brussels, pp. $271-279$

Flaquer, C., Torre, I., Arrizabalaga, A. (2007): Comparison of sampling methods for inventory of bat communities. J. Mammal., 88: 526 - 533. DOI: 10.1644/06MAMM-A-135R1.1

Fons, R., Grabulosa, I., SAINT Girons, M. C., GALÁNPuchades, M. T., Feliu, C. (1988): Incendie et cicatrisation des ecosystemes mediterraneens, dynamique du repeuplement en micromammiferes. Vie Milieu, 38: 259 - 280 Fuentes, E. R., CAMPusAnO, C: (1985): Pest outbreaks 
and rainfall in the semi-arid region of Chile. J. Arid. Env., 8: $67-72$

Fuentes, M. V., Galán-Puchades, M. T., Cerezuela, A. M. (1998): Insectívoros y roedores de la Sierra Calderona (Comunitat Valenciana). Dinámicas de recolonización y estudio helmintoecológico postincendio. Galemys, 10: 37 - 58 Fuentes, M. V., Sainz, S., Galan-Puchades, M. T. (2005): The helminth community of the common shrew in a post-fire regenerated Mediterranean ecosystem. Helminthologia, 42: $31-34$

Fuentes, M.V., Sainz-Elipe, S., Galan-Puchades, M.T. (2007): Ecological study of the wood mouse helminth community in a burned Mediterranean ecosystem in regeneration five years after a wildfire. Acta Parasitol., 52: 403 - 413

Galán-Puchades, M. T., Fuentes, M. V. (1996): Parasites and fire. Parasitol. Today, 12: 327

Galán-Puchades, M. T., Fuentes, M. V., Cerezuela, A. M., Fons, R., MAsComa, S. (1999): A proposed methodology for the use of helminth parasites as biological tags in the study of postfire ecosystem regeneration processes. Vie Milieu, 49: 45 - 50

Gotelli, N. J., Colwell, R. K. (2001): Quantifying biodiversity: procedures and pitfalls in the measurement and comparison of species richness. Ecol. Letters, 4: 379 - 391. DOI: 10.1046/j.1461-0248.2001.00230.x

Gotelli, N. J., EnTSMinger, G. L. (2001): EcoSim: Null models software for ecology. Version 7.0. Acquired Intelligence Inc. and Kesey-Bear. http://homepages.together.net/ $\sim$ gentsmin/ecosim.htm

Goüy de BellocQ, J., Sarà, M., Casanova, J. C., Feliu, C., Morand, S. (2003): A comparison of the structure of helminth communities in the woodmouse, Apodemus sylvaticus, on islands of the western Mediterranean and continental Europe. Parasitol. Res., 90: $64-67$

Gurnell, J., Flowerdew, J. R. (1990): Live trapping small mammals. A practical guide. The Mammal Society, London

Gutiérrez, J. R., Meserve, P. L., Jaksic, F. M., ContRERAS, L. C., HERrerA, S., VÁsqUEZ, H. (1993): Structure and dynamics of vegetation in a Chilean arid thorn scrub community. Acta Oecol., 14: $271-285$

HAIM, A., IZHAKI, I. (1994): Changes in rodent community during recovery form fire: relevance to conservation. Biodivers. Conserv., 3: $573-585$

Jovani, R., Tella, J. L. (2006): Parasite prevalence and sample size: misconceptions and solutions. Trends Parasitol., 22: 214 - 218. DOI: 10.1016/j.pt.2006.02.011

JuBETE, F. (2007): Apodemus sylvaticus (Linnaeus, 1758). In Palomo, L. J., Gisbert, J., Blanco, J. C. (Eds) Atlas y Libro Rojo de los Mamíferos terrestres de España. Dirección General de Conservación de la Naturaleza-SECEMSECEMU, Madrid, pp. 449 - 451

Kadlec, D., Simkova, A., Jarkovsky, J., Gelnar, M. (2003): Parasite communities of freshwater fish under flood conditions. Parasitol. Res., 89: 272 - 283

LAFFERTY, K. D. (1997): Environmental parasitology: what can parasites tell us about human impacts on the environment? Parasitol. Today, 13: 251 - 255
LudwiG, J. A., ReYNOLDS, J. F. (1988): Statistical Ecology. A primer on methods and computing. John Wiley and Sons, New York

Marcogliese, D. J., Cone, D. K. (1997): Parasite communities as indicators of ecosystem stress. Parassitologia, 39: $227-232$

Meserve, P. L., Milstead, B., Gutiérrez, J. R. (2001): Results of a food addition experiment in a north-central Chile small mammal assemblage, evidence for the role of "bottom-up" factors. Oikos, 94: 548 - 556. DOI: 10.1034/j.1600-0706.2001.940316.x

Milazzo, C., Aloise, G., Cagnin, M., Di Bella, C., Geraci, F., Feliu, C., CASAnOVA, J. C. (2005): Helminths of Apodemus sylvaticus (Muridae) distributed on the southern European border (Italian Peninsula). Vie Milieu, 55: $45-51$

Milazzo, C., Di Bella, C., Casanova, J. C., Ribas, A., CAGNIN, M. (2010): Helminth communities of wood mouse (Apodemus sylvaticus) on the river Avena (Calabria, southern Italy. Hystrix It. J. Mamm., 21 (2): 171 - 176. DOI: 10.4404/hystrix-21.2-4477

Mittelbach, G., Steiner, C. F., Scheiner, S. M., Gross, K. L., Reynolds, H. L., Waide, R. B., Willig, M. R., DoDson, S. I., Gough, L. (2001): What is the observed relationship between species richness and productivity? Ecology, 82: 2381 - 2396

Monimeau, L., Mouillot, D., Fons, R., Prodon, R., MARCHAND, B. (2002): Impact of prescribed burning on the survival rates of the wood mouse (Apodemus sylvaticus). Acta Oecol., 23: 51 - 58. DOI: 10.1016/S1146609X(02)01133-5

MONTGOMERY, W. I. (1999): Apodemus sylvaticus (Linnaeus, 1758). In: Mitchell-Jones, A. J., AMORI, G., Bogdanowicz, W., KrystufeK, B., Reijnders, P. J. H., Spitzenberger, F., Stubbe, M., Thissen, J. B. M., Vohralík, V., ZIMA, J. (Eds) The Atlas of European Mammals. T and AD Poyser, London, pp. $274-275$

MORENO, J. M., OECHEL, W. C. (1994): The role of fire in Mediterranean Ecosystems, Ecological studies., SpringerVerlag, New York

MORRIS, D. W. (1996): Coexistence of specialist and generalist rodents via habitat selection. Ecology, 77: 2352 2364. DOI: $10.2307 / 2265737$

Nieberding, C., Morand, S., Libois, R., Michaux, J. R. (2006): Parasites and the island syndrome: the colonization of the western Mediterranean islands by Heligmosomoides polygyrus (Dujardin, 1845). J. Biogeogr., 33: 1212 - 1222. DOI: $10.1111 /$ j.1365-2699.2006.01503.x

OBON, B. (1997): Recuperació de la vegetació després del gran incendi de 1994 a Gualba. La Sitja del Llop, 14: 4 - 5 Ondríková, J., Miklisová, D., RiBAs, A., StAnKo, M. (2010): The helminth parasites of two sympatric species of the genus Apodemus (Rodentia, Muridae) from south-eastern Slovakia. Acta Parasitol., 55 (4): 369 - 378. DOI: 10.2478/s11686-010-0043-1

Prodon, R., Fons, R., Athias-Binche, F. (1987): The impact of fire on animal communities in mediterranean area. In: Trabaud, L. (Ed) The Role of Fire in Ecological Sys- 
tems. SPB Academic Publishing, The Hague, pp. $121-157$ Ribas, A., Barbosa, A. M., Casanova, J. C., Real, R., FELIU, C., VARGAS, J. M. (2007): Geographical patterns of the species richness of helminth parasites of moles Talpa spp. in Spain: separating the effect of sampling effort from those of other conditionating factors. Vie Milieu, 56: $1-8$ Sainz-Elipe, S., Galan-Puchades, M. T., Fuentes, M. V. (2007): The helminth community of the Mediterranean mouse, Mus spretus, in a post-fire regenerated Mediterranean ecosystem. Helminthologia, 44: 107 - 111. DOI: 10.2478/s11687-007-0015-7

Slade, N. A., Blair, S. M. (2000): An empirical test of using counts of individuals captured as indices of population size. J. Mammal., 81: 1035 - 1045. DOI: 10.1644/1545-1542(2000)081<1035: AETOUC >2.0.CO;2

Terrades, J. (1996): Ecologia del foc. Edicions Proa, Barcelona

RECEIVED JULY 10, 2012
Torre, I., ArrizabalagA, A. (2008): Habitat preferences of the bank vole (Myodes glareolus) in a Mediterranean mountain range. Acta Theriol., 53 (3): 241 - 250. DOI: 10.1007/BF03193120

Torres, J., Blasco, S., Feliu, C., Arrizabalaga, A., Montagud, E. (1992): Las helmintofaunas de micromamíferos (insectívoros y rodedores) como indicadoras del grado de recuperación del Macizo de Montserrat (Cataluña, España) después del incendio forestal. Cir. Far., 313: $77-88$

Trabaud, L., Prodon, R. (1993): Fire in Mediterranean Ecosystems, Ecosystems Research Report 5., Comission of the European communities, Brussels

ZAR, J. H. (1996): Biostatistical analysis. Prentice Hall, New Jersey 